\title{
Investigation into the microbial flora of healing and non-healing decubitus ulcers
}

\author{
DIANA C DALTREY, B RHODES, JG CHATTWOOD \\ From the School of Health and Applied Sciences, Leeds Polytechnic, Leeds LS1 3HE
}

SUMMARY Seventy-four pressure lesions in fifty-three geriatric patients were observed at weekly intervals to determine the bacterial flora and the healing index of each lesion, expressed as $\left[\frac{\text { initial area of lesion }\left(\mathrm{cm}^{2}\right) \text { - final area of lesion }\left(\mathrm{cm}^{2}\right)}{\text { time in days }}\right]$. The micro-organisms which caused infection

included Staphylococcus aureus, Proteus mirabilis, Pseudomonas aeruginosa, Bacteroides fragilis and Bacteroides asaccharolyticus. Many lesions contained a mixed flora. $P$ mirabilis and Ps aeruginosa were associated with necrotic $(\mathrm{p}<0.005)$ and enlarging $\left(\mathrm{p}<5 \times 10^{-7}\right)$ lesions. Bacteroides spp were associated with necrotic lesions $(\mathrm{p}<0.05)$. The presence of $S$ aureus in a lesion was not associated with any particular trend in healing index. The implications of the microbiological findings are discussed.

Decubitus ulcers are known to harbour a flora of aerobic and sometimes anaerobic bacteria. However, there seems to be no consensus of opinion on how this may affect the healing process. Bendy et al., in a study of topical gentamicin treatment, concluded that "suppression of growth of bacterial pathogens is the decisive factor in the healing of decubiti." 1 Morgan cites absence of pressure, debridement of dead tissue and control of infection as the three factors determining success of topical treatments. ${ }^{2}$ The opposite view is summarised in a British Medical Journal leader "There is little place for antibiotics. Pressure sores, like varicose ulcers heal when the underlying cause is eliminated. Bacteria merely colonise the ulcer-they do not cause it."3

The aim of this investigation was to study the bacterial flora of a series of decubitus ulcers of varying severity and to try to relate the types and numbers of organisms present to the types and healing rates of the lesions.

\section{Patients and methods}

SUBJECT SAMPLE

Fifty-three patients ( 11 men, 42 women) admitted to the geriatric unit of a large general hospital were included in the study, which was carried out in conjunction with a clinical trial of karaya gum power (sterculia or Indian tragacanth). ${ }^{4}$ Ages ranged from 64 to $97 \mathrm{yr}$ (mean $79 \mathrm{yr}$ ). Decubiti were studied from the time the patient was admitted or the lesion identified until the lesion healed or the patient was discharged or died. (Range 1-47 wk, mean $5 \mathrm{wk}$.) Clinical data for the patients were collated.

Pressure lesions were classified as superficial, ulcerative, or necrotic by the nurse researcher. Most superficial and some ulcerative lesions were treated with Tincture Benzoin Co, Karaya, or Karaya with povidone iodine. Most necrotic and the more severe ulcerative lesions were treated with Eusol. Other treatments occasionally used were Paranet, Cicatrin, dextranomer, Aserbine and zinc sulphate.

In fourteen patients with several lesions, all were fully studied but only the largest lesion from each patient was included in the statistical analysis. Five patients were excluded from some of the analysis because no healing index could be calculated for reasons of medical management.

\section{MEASUREMENT OF HEALING RATE}

Lesions were measured initially, at weekly intervals, and when the patient left the study. Except on rare occasions, the nurse researcher made all the measurements. A transparent rule was used to measure the longest wound axis in millimetres (A) and a second measurement was made at right angles to the first (B). Both measurements passed through the midpoint. The area of the lesion was taken to be $\pi \frac{1}{2} \mathrm{~A} \frac{1}{2} \mathrm{~B}$. This method of measurement was adopted since a planimeter was not available for most of the study. To 
assess the error, twelve lesions were traced and measured by planimetry in parallel with the original method. Agreement between the methods was determined by linear regression analysis and was $\operatorname{good}(\mathrm{r}=0.92, \mathrm{p}<0.001)$.

Eventually a Healing Index (HI) was calculated for each lesion by subtracting the final area of the lesion from its initial area and dividing by the intervening time in days.

\section{BACTERIOLOGICAL METHODS}

\section{Sampling}

The semiquantitative sampling technique was designed to reflect comparative levels of colonisation in different lesions and in one lesion from week to week.

A serum-coated swab was moistened in sterile one quarter strength Ringer solution and used to swab an area of $1 \mathrm{~cm}^{2}$ at the centre of the ulcer through a sterile metal template. The swab was aseptically broken off into $2 \mathrm{ml}$ Ringer solution in a bijou bottle and the organisms eluted by vigorous shaking for exactly one minute. Serial tenfold dilutions of the eluate were made, and the count estimated by the method of Miles and Misra. ${ }^{5}$

Preliminary experiments showed that a count of $\geqslant 10^{4} / \mathrm{cm}^{2}$ obtained by this method correlated with heavy growth on at least the first two quadrants of a streak plate prepared from a routine swab of the same lesion. Since it is virtually impossible clinically to assess damage due to infection in ischaemic lesions, the term infection is used to mean the persistent presence of a micro-organism at levels $>10^{4} / \mathrm{cm}^{2}$.

In twenty patients the anaerobic flora of the lesions was systematically investigated. A separate swab was taken from areas of the lesion judged most likely to yield anaerobes-for example, necrotic tissue, undercut edges, and this was immersed in Carey Blair anaerobic transport medium for transit to the laboratory. Conventional streak plates were prepared from these swabs and the plates assessed for significant levels of growth in the normal manner.

\section{Isolation and identification}

Routine counts were carried out on blood agar (Columbia agar base $+5 \%$ horse blood) MacConkey's agar and cetrimide agar (nutrient agar $+0.03 \%$ cetrimide). Aerobic plates were incubated at $37^{\circ} \mathrm{C}$ for $24 \mathrm{~h}$ before examination. Plates were then reincubated and checked after a further $24 \mathrm{~h}$.

For anaerobic work the media used were vitamin $\mathrm{K}_{1}$-blood agar (blood agar $+10 \mu \mathrm{g} / \mathrm{ml}$ vitamin $\mathrm{K}_{1}$ ), neomycin-vitamin $\mathrm{K}_{1}$-blood agar (blood agar +10 $\mu \mathrm{g} / \mathrm{ml}$ vitamin $\mathrm{K}_{1}+100 \mu \mathrm{g} / \mathrm{ml}$ neomycin base activity) and kanamycin-vancomycin-laked blood $\frac{0^{*}}{5}$ agar (Columbia agar base $+5 \%$ laked horse blood $+0.5 \mu \mathrm{g} / \mathrm{ml}$ kanamycin $+0.5 \mu \mathrm{g} / \mathrm{ml}$ vancomycin). These plates were either freshly poured or stored $\stackrel{\text { ? }}{+}$ anaerobically and were warmed before inoculation. Anaerobic plates were incubated in $90 \% \mathrm{H}_{2}, 10 \%$ 흘 $\mathrm{CO}_{2}$ in Gaspak jars at $37^{\circ} \mathrm{C}$ for $48 \mathrm{~h}$ before examination. Plates were then reincubated anaerobically $\cong$ and checked a week after inoculation.

Aerobic bacteria were identified according to themethods of Cowan and Steel. ${ }^{6}$ Anaerobic bacteria were identified according to the methods in the $\vec{\omega}$ Wadsworth manual. ${ }^{7}$ Staphylococci were phage- $-\frac{9}{2}$ typed by the Public Health Laboratory Service.? Streptococci were grouped using Phadebact reagents ${ }_{+}^{\omega}$ (ABCG) with Lancefield grouping by the acid $\checkmark$ extraction method for group D. Some group $B_{O}$ streptococci were phage-typed by the Streptococcal Reference Laboratory, Colindale. Ps aeruginosa isolates were pyocine-typed by the method of Govan and Gillies. ${ }^{8}$

\section{Results}

Table 1 shows the range of organisms isolated. Normal skin flora such as Staphylococcus epidermidis, Micrococcus and coryneforms were not studied further. The aerobic and anaerobic bacteria which

Table 1 Range of organisms isolated. Number of patients examined for aerobes: 53; for anaerobes: 20

\begin{tabular}{|c|c|}
\hline Aerobic bacteria & No of patients \\
\hline \multicolumn{2}{|l|}{ Gram-positive cocci } \\
\hline Staphylococcus aureus, $S$ epidermidis & 44,31 \\
\hline Micrococcus spp & 15 \\
\hline Streptococcus spp & 31 \\
\hline $\mathbf{A}, \mathbf{B}, \mathbf{C}, \mathbf{D}, \mathbf{G}$, other & $1,6,6,28,6$ \\
\hline \multicolumn{2}{|l|}{ Gram-positive bacilli } \\
\hline Coryneforms & 31 \\
\hline Bacillus laterosporus & 1 \\
\hline \multicolumn{2}{|l|}{ Gram-negative bacilli } \\
\hline Proteus spp & 27 \\
\hline mirabilis, morgani, rettgeri, other & $25,2,1,1$ \\
\hline Escherichia coli & 19 \\
\hline Klebsiella pneumoniae (sensu lato) & 8 \\
\hline Citrobacter freundii & 1 \\
\hline Hafnia alvei & 1 \\
\hline Acinetobacter spp & 2 \\
\hline Moraxella spp & 2 \\
\hline Alcaligenes sp & 1 \\
\hline Pseudomonas aer uginosa & 15 \\
\hline \multicolumn{2}{|l|}{ Anaerobic bacteria } \\
\hline \multicolumn{2}{|l|}{ Bacteroides fragilis group } \\
\hline fragilis, ovatus, thetaiotamicron, vulgatus, & \\
\hline $\begin{array}{l}\text { other } \\
R\end{array}$ & $5,1,2,1,3$ \\
\hline B asaccharolyticus & 4 \\
\hline Fusobacterium necrophorum & 1 \\
\hline Clostridium spp & 5 \\
\hline perfringens, sporogenes, cadaveris & $3,1,1$ \\
\hline Gram-positive non-sporing rods & 2 \\
\hline Gram-positive cocci & 9 \\
\hline \multicolumn{2}{|l|}{ Yeasts } \\
\hline$\overline{C a n d i d a}$ spp & 3 \\
\hline
\end{tabular}


Table 2 Recovery of significant numbers of aerobes and anaerobes in relation to healing index and lesion type

\begin{tabular}{|c|c|c|c|c|c|}
\hline \multirow[t]{3}{*}{ Micro-organism } & \multicolumn{5}{|c|}{$\%$ lesions yielding micro-organism } \\
\hline & \multirow{2}{*}{\multicolumn{2}{|c|}{$\begin{array}{l}* \text { Healing index } \\
\leqslant 0>0\end{array}$}} & \multicolumn{3}{|c|}{ Lesion type } \\
\hline & & & Necrotic & Ulcerative & $\begin{array}{l}\text { Super- } \\
\text { ficial }\end{array}$ \\
\hline \multirow{6}{*}{$\begin{array}{l}\text { Aerobes } \\
\text { Staphylococcus } \\
\text { aureus } \\
\text { Streptococcus spp } \\
\text { Escherichial } \\
\text { Klebsiella spp } \\
\text { Proteus spp } \\
\text { Pseudomonas } \\
\text { aeruginosa } \\
\text { Any aerobe }\end{array}$} & \multicolumn{2}{|c|}{$\mathrm{n}=14 \mathrm{n}=34$} & $n=12$ & $\mathrm{n}=17$ & $\mathrm{n}=24$ \\
\hline & 21 & 50 & 33 & 41 & 46 \\
\hline & 14 & 12 & 25 & 6 & 17 \\
\hline & 21 & $\mathbf{0}$ & 17 & $\mathbf{0}$ & 4 \\
\hline & 57 & 3 & 50 & 12 & 8 \\
\hline & $\begin{array}{l}43 \\
86\end{array}$ & $\begin{array}{r}6 \\
53\end{array}$ & $\begin{array}{l}50 \\
83\end{array}$ & $\begin{array}{l}18 \\
65\end{array}$ & $\begin{array}{r}4 \\
50\end{array}$ \\
\hline Anaerobes & $\mathrm{n}=\mathbf{7}$ & $\mathbf{n}=10$ & $\mathrm{n}=6$ & $\mathrm{n}=5$ & $\mathrm{n}=9$ \\
\hline Bacteroides spp & & 10 & 67 & 40 & \\
\hline Fusobacterium spp & p 14 & 0 & 17 & 0 & 0 \\
\hline Clostridium spp & 14 & 10 & 17 & 20 & $\mathbf{0}$ \\
\hline Anaerobic cocci & 0 & 10 & 33 & 0 & $\mathbf{0}$ \\
\hline Any anaerobe & 57 & 10 & 67 & 40 & $\mathbf{0}$ \\
\hline Any micro-organism & 86 & 53 & 83 & 65 & 50 \\
\hline
\end{tabular}

$* \mathbf{0}$ static or enlarging lesions.

$>0$ healing lesions.

caused infection are shown in Table 2. Gramnegative aerobic rods infected $71 \%$ of decubiti with $\mathrm{HI} \leqslant 0$ compared to only $9 \%$ of resolving lesions. Pseudomonas aeruginosa and Proteus mirabilis were found most frequently. There was a significant association between $\boldsymbol{P}$ mirabilis and necrotic lesions (p $<0.005 \chi^{2}$ test) and $P$ s aeruginosa and necrotic lesions $\left(\mathrm{p}<0.005 \chi^{2}\right.$ test). Decubiti infected by either of these organisms had a significantly lower $\mathrm{HI}$ than decubiti not so infected $(P$ mirabilis $\mathrm{p}<$ 0.00003, Ps aeruginosa p < 0.006; Mann Whitney $U$ test). There was a highly significant association between $\boldsymbol{P}$ mirabilis or $\boldsymbol{P s}$ aeruginosa or both and enlarging lesions $(\mathrm{HI}<0)\left(\mathrm{p}<5 \times 10^{-7} \chi^{2}\right.$ test $)$.

Twenty patients were examined for anaerobic flora. Six were infected with a mixture of aerobes and anaerobes and eight with aerobes alone. No lesion was infected by anaerobes alone. There was a significant association between anaerobic infection and necrotic lesions ( $p<0.05$, Fisher test). Decubiti infected by mixtures including anaerobic bacteria had a significantly lower HI than other lesions (p $<0.025$ Mann Whitney $U$ test). However $\boldsymbol{P}$ mirabilis and $\boldsymbol{P s}$ aeruginosa were also present in some cases making interpretation difficult.

Comparison of lesions infected with $S$ aureus alone with uninfected lesions showed no significant difference in HI between the groups. Fourteen different phage types and a number of non-typable isolates of $S$ aureus were found; none was associated with any one category of lesion or with lowered HI.
Many lesions were colonised transitorily rather than infected. Streptococci were also frequently present as transients. Nine patients only were infected with streptococci (six group D, one group C, one untyped and one group B). Indistinguishable strains of group B Streptococcus were isolated from the pressure lesion and the vagina of the last mentioned patient.

Altogether 20 lesions were uninfected, 15 were infected by a single organism ( $S$ aureus 12; $P S$ aeruginosa $2 ; \boldsymbol{P}$ mirabilis 1$)$ and 18 were infected by a mixture of organisms.

Povidone iodine was applied to superficial or ulcerative lesions in seven patients. There was no significant difference in either the incidence of infection or in the healing rate in patients treated with karaya + povidone iodine compared to those treated with karaya alone (Fisher test, Mann Whitney $U$ test).

Since all patients with enlarging lesions died, clinical data were examined to establish whether these patients differed significantly in underlying illness, nutritional status, or age, from those with healing lesions.

The same range of illnesses occurred in both the patients who died and those who survived with the exception of carcinoma which occurred only in the former group. The most frequent diagnoses were cerebrovascular accident and bronchopneumonia: there was no significant difference in the incidence of these conditions between dying and surviving groups ( $\chi^{2}$ test). The incidences of diabetes, carcinoma, and anaemia are shown in Table 3 . Weight loss occurred significantly more often in the group who died $\left(\chi^{2} \mathrm{p}<0.05\right)$. Only two patients were on steroid treatment during the study and in both cases their lesions healed completely.

Patients who died were subgrouped into those with enlarging lesions and those with static or healing lesions: these groups were similar concerning underlying illness.

\section{Discussion}

Since numerous factors affect the healing process it is difficult to determine what effects, if any, are due to micro-organisms: the results should therefore be interpreted with caution.

The organisms particularly associated with necrotic lesions were $\boldsymbol{P}$ mirabilis, $\boldsymbol{P s}$ aeruginosa and Bacteroides spp. Decubitus ulcers are ischaemic lesions and local resistance to infection will diminish as the lesion becomes more severe. Lack of local resistance and the presence of dead tissue may allow these organisms to gain a foothold. Anaerobes always occurred in combination with aerobes which may have helped to provide a suitable environment for 
Table 3 Clinical data in relation to patient survival and healing index of lesion

\begin{tabular}{|c|c|c|c|c|c|c|}
\hline & \multicolumn{3}{|c|}{ State of lesion in patients who died } & \multicolumn{3}{|c|}{ State of lesion in patients who survived } \\
\hline & Enlarging $(H I<0)$ & Static $(H I=0)$ & Healing $(H I>0)$ & Enlarging $(H I<0)$ & Static $(H I=0)$ & Healing $(H I>0)$ \\
\hline $\begin{array}{l}\text { No of patients } \\
\text { Mean age (yr) } \\
\text { No of patients showing: }\end{array}$ & $\begin{array}{l}11 \\
78 \cdot 3\end{array}$ & $\begin{array}{r}3 \\
79\end{array}$ & $\begin{array}{c}6 \\
78 \cdot 8\end{array}$ & 0 & 0 & $\begin{array}{l}28 \\
79 \cdot 4\end{array}$ \\
\hline Weight loss & 7* & $\mathbf{0}$ & 2* & & & 2 \\
\hline Anaemia $(\mathrm{Hb}<10 \mathrm{~g} / \mathrm{dl})$ & 1 & 1 & 2 & & & 5 \\
\hline Diabetes & 1 & 1 & 0 & & & 2 \\
\hline $\begin{array}{l}\text { Carcinoma } \\
\text { Healing index: }\end{array}$ & 2 & 2 & $\mathbf{0}$ & & & 0 \\
\hline Mean & -211 & $\mathbf{0}$ & 13.8 & & & $15 \cdot 3$ \\
\hline Range & -1024 to -0.6 & $\mathbf{0}$ & 1.7 to 33.5 & & & 1.4 to 78.5 \\
\hline $\begin{array}{l}\text { Class of lesion: } \\
\text { Necrotic }\end{array}$ & & & & & & \\
\hline $\begin{array}{l}\text { Necrotic } \\
\text { Ulcerative }\end{array}$ & 6 & $\mathbf{0}$ & 2 & & & 2 \\
\hline $\begin{array}{l}\text { Ulcerative } \\
\text { Superficial }\end{array}$ & $\begin{array}{l}3 \\
2\end{array}$ & $\begin{array}{l}2 \\
1\end{array}$ & $\begin{array}{l}3 \\
1\end{array}$ & & & $\begin{array}{r}8 \\
18\end{array}$ \\
\hline
\end{tabular}

$\mathrm{HI}=$ healing index.

* One patient on diuretics.

anaerobic growth in the decubitus. The range of anaerobes and their distribution in the lesion types are largely in agreement with the finding of Peromet. ${ }^{9}$

Properties of the micro-organisms themselves seem to be important, for Enterobacteriaceae other than Proteus spp only rarely became established in the mixed culture in enlarging lesions and never became established in any other lesions. Similarly, all members of the Bacteroides fragilis group were isolated but only $\boldsymbol{B}$ fragilis (formerly $\boldsymbol{B}$ fragilis ss fragilis) became established in the lesions.

The presence of Proteus spp and Ps aeruginosa cannot be entirely explained by a predilection for necrotic tissue. Only 6/11 enlarging lesions were classed as necrotic (see Table 3 ). Of the remaining five lesions, four contained Proteus spp/Ps aeruginosa and it was the least severe lesion in the group (HI -0.6 ) which was free of these organisms. Amongst patients with healing lesions Proteus spp or Ps aeruginosa infection or both was found in only $3 / 33$ non-necrotic lesions.

Examination of clinical data did not reveal an obvious explanation for the enlarging lesions. All the patients in the study were old, but ages were similar in patients with enlarging and with healing lesions, as were the underlying illnesses. Of the four patients with carcinoma two had enlarging lesions infected by Gram-negative aerobes; the other two had static, uninfected lesions. Four patients had mild diabetes: one suffered a necrotic enlarging lesion infected by Ps aeruginosa and one an ulcerative lesion infected with Bacteroides spp and Streptococcus group D, which remained static. The other two diabetics had only superficial, healing lesions, one uninfected, the other infected with $S$ aureus.

Of the twenty patients who died, nine had lost weight. Seven of these were in the group with enlarging lesions, suggesting an association of this $\vec{c}$ condition with weight loss, but this did not reach significance at the $95 \%$ level (Fisher test). If weight loss is taken as an indication of poor nutritional $ळ$ status then this is not an invariable concomitant of an enlarging lesion, since the two patients with the most severe lesions of all were not losing weight and had a dietary intake classed as normal.

Although poor nutritional status would predispose patients to infection, an infection once initiated $\stackrel{\otimes}{\circledR}$ might contribute to general debilitation of the $\overrightarrow{\vec{A}}$ patient, and Proteus spp or $P$ s aeruginosa once $\frac{O}{3}$ established in a lesion might contribute to local $\bar{D}$ damage thereby delaying or preventing healing.

Axler et al. found that Gram-negative rods present as predominant members of the flora of cutaneous? ulcers, precluded porcine skin grafts from promoting $\frac{5}{3}$ healing. Predominantly Gram-positive flora on the ulcer surface allowed healing to take place, although $\frac{}{3}$ $S$ aureus retarded the process. ${ }^{10}$

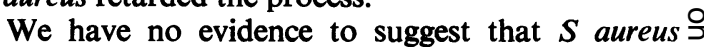
delays healing, but we were comparing lesions $?$ persistently colonised by $>10^{4} S$ aureus $/ \mathrm{cm}^{2}$ with lesions containing less than this number, whereas $N$ Axler was looking for presence or absence of the organism.

The presence of large numbers of micro-organisms $\mathrm{c}$ in decubiti is hazardous since there is a risk to the patient of invasion and septicaemia ${ }^{11}$ and a risk to other patients of cross-infection. ${ }^{12} 13$

Pyocine typing of Ps aeruginosa and phage-typing? of $S$ aureus and Streptococcus group B suggested that some sharing of organisms occurred in this $\frac{O}{D}$ series of geriatric patients. Neglect of decubitus ulcers $\frac{\rho}{+}$ as a potential source of pathogens may lead to $\stackrel{\varnothing}{\varnothing}$ avoidable cross-infection.

We suggest that Proteus spp and Ps aeruginosa 
infection of decubiti in elderly patients may be of greater clinical importance than presently acknowledged, and that this merits further investigation. It seems unwise to view such infections as "merely colonisation."

The authors wish to thank the staff of the hospital concerned and the microbiology technicians of the School of Health and Applied Sciences for their co-operation and assistance, and Dr WC Noble for his help and encouragement.

\section{References}

${ }^{1}$ Bendy RH, Nuccio PA, Wolfe E, et al. Relationship of quantitative wound bacterial counts to healing of decubiti: effect of topical gentamicin. Antimicrob Agents Chemother 1964;4:147-55.

2 Morgan J Elizabeth. Topical therapy of pressure ulcers. Surg Gynecol Obstet 1975;141:945-7.

${ }^{3}$ British Medical Journal. Treating pressure sores. $\mathrm{Br} \mathrm{Med} \mathrm{J}$ $1978 ; \mathrm{i}: 1232$.

4 Rhodes B, Daltrey DC, Chattwood JG. The treatment of pressure sores in geriatric patients. A trial of sterculia powder. Nursing Times 1979;75 (9):365-8.

5 Miles AA, Misra SS. The bactericidal power of the blood. J Hyg (Lond) 1938;38:732.
- Cowan ST. Cowan and Steel's manual for the identification of medical bacteria. Cambridge: CUP, 1974.

' Sutter VL, Vargo VL, Finegold SM. Wadsworth anaerobic bacteriology manual. University of California, 1975.

${ }^{8}$ Govan JRW, Gillies RR. Further studies in the pyocine typing of Pseudomonas pyocyanea. J Med Microbiol $1969 ; 2: 17-25$.

- Peromet M, Labbe M, Yourassowsky E, Schoutens E. Anaerobic bacteria isolated from decubitus ulcers. Infection 1973;1:205-7.

${ }^{10}$ Axler DA, Terleckyj B, McCarthy DJ, Kwasnik RE, Novicki D, Culliton P. The efficacy of porcine skin grafts for treating non-healing cutaneous ulcers. Part III: Microbiologic Studies. J Am Podiatry Assoc 1978; 68:141-50.

11 Galpin JE, Chow AW, Bayer AS, Guze LB. Sepsis associated with decubitus ulcers. Am J Med 1976;61: 346-50.

12 Alder VG, Gillespie WA. Pressure sores and staphylococcal cross-infection. Detection of sources by means of settle plates. Lancet 1964 ;ii:1356-68.

13 Wysocki J, Mulholland SG, McGarrity GJ, Ximenes M, Blakemore WS. The role of wounds in the epidemiology of nosocomial infections due to Pseudomonas aeruginosa. Invest Urol 1974;11:370-3.

Requests for reprints to: Dr Diana C Daltrey, School of Health and Applied Sciences, Leeds Polytechnic, Calverley Street, Leeds LS1 3HE, England. 